\title{
O fim da velha divisão? Público e privado na era da internet
}

\author{
Luis Felipe Miguel* \\ https://orcid.org/0000-0002-0420-6327 \\ Adriana Veloso Meireles* \\ http://orcid.org/0000-0002-7095-7022
}

Central para o entendimento do mundo social, a separação entre uma esfera pública e outra privada é pressuposta em muitas de nossas instituições e em nosso ordenamento jurídico. Mas a localização da fronteira entre as duas esferas é disputada: é uma localização culturalmente formada, sensível ao contexto histórico e que se transforma de acordo com o discurso que é mobilizado. A distinção, por vezes, é entre o que é político e o que não é político; por outras, entre o que é do governo e o que é do mercado ou até mesmo o que está dentro ou fora das portas de casa. Sistematizando diferentes entendimentos da dicotomia, Jeff Weintraub destaca dois critérios principais: "o que está escondido versus o que se encontra aberto, revelado ou acessível" e "o que é individual versus o que é coletivo, ou afeta o interesse de uma coletividade de indivíduos" (Weintraub, 1997, p. 5). A publicidade, assim, é uma questão de visibilidade ou de abrangência do interesse. Os dois critérios não são estanques entre si; a visibilidade do que é público é condição para que todos possam ao menos acompanhar aquilo que lhes diz respeito, constatação que funda o "princípio transcendental da publicidade" de Kant ([1786] 1995, p. 165). Mas os critérios tampouco se sobrepõem perfeitamente. Estabelecimentos comerciais privados precisam atender ao público; decisões privadas de investimento têm impacto coletivo, isto é, público; interações pessoais que ocorrem em ruas, praças ou outros espaços públicos podem só dizer respeito aos participantes, isto é, são privadas, ao

\footnotetext{
* Universidade de Brasília, Brasília, Brasil.
} 
passo que as violências que ocorrem em espaços privados exigem a intervenção do poder público.

A despeito dessa zona cinzenta, a tradição liberal vê a separação entre público e privado como uma garantia fundamental contra a tirania. Ela seria a precondição para o estabelecimento de uma zona de liberdade pessoal, invulnerável ao arbítrio estatal. Outras correntes de pensamento a denunciam como nociva, como fizeram e ainda fazem, de diferentes maneiras, o movimento operário, o movimento feminista e o movimento ambientalista. O "privado" aparece, então, como uma esfera em que as desigualdades se reproduzem sem questionamento e abusos de poder podem ser cometidos, ao abrigo do controle da coletividade. Isso não leva necessariamente à ideia de abolição da fronteira (cf. Cohen, 1997), mas a uma perspectiva mais crítica e a maior sensibilidade a seus problemas.

Longe de convergir para um consenso, a compreensão de como a divisão público/privado se configura e qual o valor a ser atribuído a ela parece cada vez mais imersa em polêmica. Ainda assim, ela é atuante, no mundo e nas representações que fazemos dele.

A internet e outras tecnologias, cujo uso ela potencializa, estão impondo desafios crescentes à possibilidade de operar com um modelo de duas esferas separadas. Saudada pela literatura como uma nova e potente esfera pública, a internet foi apropriada pela maior parte das pessoas como um anexo de seus espaços privados. Diante de um contexto de ambiguidade e de baixa congruência entre promessas iniciais e usos efetivos socialmente referendados, "as pesquisas acadêmicas sobre a internet como uma esfera pública apontam para a conclusão de que as tecnologias digitais criam um espaço público, mas não necessariamente conformam uma esfera pública” (Papacharissi, 2009, p. 236). A diferença, explica a autora, é que o espaço público amplia a discussão, ao passo que a esfera pública deve ampliar a democracia (Papacharissi, 2009, p. 236).

A resposta é pouco convincente, ancorada em uma divisão conceitual obscura e que remonta a uma normatividade implícita e questionável. Ela serve, sobretudo, para demonstrar como o encontro do público e privado nos ambientes virtuais não permite adaptação fácil aos modelos preexistentes. Entre as muitas questões que surgem desse encontro inesperado, cinco são importantes para a investigação proposta neste paper.

(1) A homologia entre localização espacial e acesso a uma ou outra esfera, que nunca foi perfeita, está cada vez menos sustentável. A interação com o "público" se dá a partir de espaços “privados”, que portanto funcionam menos como espaços de efetiva privacidade. É a partir da tela individual que ocorrem as principais trocas na rede, seja em espaços considerados como públicos, isto é, potencialmente acessíveis 
a todos, como blogs ou redes sociais, seja em comunicações supostamente privadas, como troca de e-mails. Com isso a separação das esferas se torna opaca. $O$ fator territorial se dissolve, dado que, com a internet, cada pessoa pode estar em sua casa e, a partir dela, falar para um público amplo e desconhecido. Na realidade, a localização espacial pouco importa, desde que haja conexão à rede.

(2) A familiaridade com o espaço físico "privado" e com as pessoas do círculo próximo, com quem se dá a interlocução cotidiana, leva a que as pessoas muitas vezes não se deem conta do alcance potencial de suas mensagens. Conversas em redes sociais, entendidas como privadas, podem vir a público, causam constrangimentos pessoais e profissionais e por vezes têm consequências importantes. Soma-se a isso a "cultura do compartilhamento" (Lyon, 2017) promovida pelas redes, que leva as pessoas a divulgarem suas opiniões, interesses, posições políticas, orientação sexual, hábitos de consumo e relações afetivas como forma de afirmação da própria identidade. Intimidade e identidade, assim, configuram-se como antitéticas; a identidade se estabelece por meio da exposição. Uma exposição, na verdade, performativa, em que a identidade apenas potencial é simulada e, no mesmo movimento, efetivada por sua presença na rede (cf. Bruno, 2008).

(3) Há uma transição sem solução de continuidade da comunicação privada para a exposição pública. Da divulgação de imagens íntimas sem consentimento às gravações ocultas de políticos e funcionários públicos, o risco de publicização indesejada está presente para todos. $\mathrm{O}$ instrumento para registro audiovisual se encontra no bolso das pessoas, em aparelhos celulares cada vez mais potentes. Comentários privados que, caso não fossem gravados, cairiam no esquecimento podem ser resgatados a qualquer momento e gerar graves repercussões. Aparentemente ninguém mais está imune a uma exposição indesejada na internet, e o fato de que o compartilhamento das informações ocorre em uma velocidade "viral" possibilita que a exposição se dê de forma descoordenada e fora de controle.

(4) A própria exposição pública perde seu contexto: ela pode ser reproduzida para outra audiência, em outro momento. É uma experiência à qual hoje todos são suscetíveis, dos particulares flagrados pelas câmaras do Google Street View aos políticos cujos discursos veiculados no YouTube atingem plateias inesperadas. São duas desconexões sobrepostas. Primeiro, o alcance potencial imediato das mensagens ultrapassa, e muito, a proximidade física, isto é, a presença a a fala podem alcançar quem não está lá. Além disso, como todas as informações são registradas e guardadas em dispositivos digitais com capacidade de armazenamento cada vez maior, não se trata apenas desse alcance imediato. A informação armazenada é resgatável em algum momento indeterminado do futuro; logo, o descompasso entre o ambiente imaginado da ação e aquele em que ocorre da exposição não é apenas espacial, mas também temporal. 
(5) Por fim, mas não menos importante, a noção de privacidade fica em suspenso diante das técnicas de vigilância onipresentes. Estados e corporações rastreiam uma grande parcela das trocas comunicativas on-line, incluindo aquelas que seriam privativas (e-mails, chats, ligações de voz), o que, no limite, torna obsoleta a ideia de "privado" como aquilo que está imune à supervisão de terceiros. $\mathrm{O}$ acesso aos dados privados promove um conhecimento amplo e detalhado sobre o comportamento do público em geral, de segmentos deles e de cada indivíduo isoladamente. Por vezes, a inteligência artificial por trás das sugestões on-line parece conhecer as preferências das pessoas melhor do que elas próprias. As consequências políticas diretas desse fenômeno foram expostas no escândalo gerado pela atuação da Cambridge Analytica, consultoria de big data, nas eleições presidenciais estadunidenses de 2016. Mas as consequências políticas de um direcionamento cada vez maior da ação das pessoas em sociedade para o consumo e para a satisfação das necessidades geradas pela publicidade comercial, embora talvez menos evidentes, não são menos profundas.

Internet, público e privado

Se a internet um dia já foi um vasto campo aberto à exploração, ou uma esfera pública interconectada (Benkler, 2006), com o passar do tempo as grandes corporações adquiriram os principais terrenos disponíveis, centralizaram todo o tráfego, passando a controlar o fluxo de informações, criando verdadeiros "jardins murados" (Dantas, 2010). Na última década observou-se a passagem do acesso à internet dos computadores pessoais aos dispositivos móveis, primeiramente com os smartphones e mais recentemente com objetos inteligentes e a internet das coisas. Somada a isso, multiplicou-se a capacidade de armazenamento de informações. Equipamentos relativamente pequenos e baratos são hoje capazes de guardar quantidades espantosas de informação, o que possibilitou o surgimento do fenômeno da big data, termo que se refere ao volume, processamento e cruzamento de dados gerados por dispositivos digitais.

A internet é pública no sentido de que tudo é registrado, mas as pessoas conduzem nesse ambiente atividades de caráter privado, como, por exemplo, a troca de correio eletrônico e conversas particulares, entre outras atividades sociais. Enquanto o correio convencional evoluiu sob a égide do princípio do sigilo postal, a correspondência eletrônica é monitorada pelas empresas, ostensivamente para gerar publicidade comercial personalizada para as pessoas. A despeito da diferença de meios - papel, envelope e carteiro de um lado, teclado, tela e fibra óptica do outro -, correio convencional e correio eletrônico cumprem exatamente o mesmo propósito. $\mathrm{O}$ fato de que o sigilo das mensagens, que no ordenamento liberal é imprescindível para o 
primeiro, seja dispensado quase sem debate no caso do segundo revela o declínio da noção até agora dominante de privacidade.

A crescente opacidade dos limites entre o que é público e o que é privado ocorre não apenas devido ao design das tecnologias e de seus algoritmos, feitos para registrar as informações, como também pela própria cultura do compartilhamento que se conforma com a eclosão do fenômeno das redes sociais. A autoexposição não se dá apenas em fotografias pessoais (selfies), mas também na divulgação de informações sobre o local em que se está (geolocalização) e, sobretudo, na exposição de preferências.

Em outras palavras, na internet são realizadas atividades políticas, econômicas, culturais, pessoais, dentre outras, que se caracterizam por "um espaço hibrido que ofusca o que é público e o que é privado, o que é cívico ou baseado em consumo, o que é coletivo e o que é pessoal" (Papacharissi, 2015, p. 23). Essa esfera virtual é caracterizada pelo acesso à informação, reciprocidade de comunicação e a comercialização de espaço on-line (Papacharissi, 2009). Além desses atributos, a forma de expressão em mídias digitais tem uma natureza calcada na "personalização, ou seja, a capacidade de organizar informações com base em uma ordem subjetiva de importância determinada pelos sujeitos" (Idem, p. 237).

É importante, aqui, marcar a diferença entre os usos potenciais da internet, abertos por suas características técnicas, e o uso historicamente construído, que seleciona algumas das potencialidades e adormece outras. Nas primeiras décadas do século passado, Bertolt Brecht ([1927-32] 2003) julgava que o rádio seria um instrumento de debate livre e amplo de ideias, já que cada pessoa disporia de um transmissor em sua própria casa e por meio dele falaria para o mundo. Mas o radioamadorismo nunca passou de um hobby de poucos, e o rádio tornou-se um meio de massa em que a separação entre emissores e receptores é estrita. Com as novas tecnologias, o resultado é menos inequívoco, mas ainda assim é possível perceber, com clareza, que a efetivação de suas virtualidades emancipatórias não é a prioridade da indústria.

No momento em que a internet emergiu, gerou uma onda de esperança em utopistas de diferentes matizes - anarcocapitalistas, radicais de esquerda, deliberacionistas. Para uns, ela seria o "vírus assassino do Estado" (Frezza, 1995); para outros, a promessa de uma auto-organização tecnologicamente mediada (Lévy, 1994). Mas o plano dos desenvolvedores da tecnologia, nos laboratórios das grandes universidades da América do Norte e nas empresas do Vale do Silício, sempre foi outro. Tratava-se de gerar não uma ágora, mas um grande mercado virtual. Muito mais do que um instrumento de autoexpressão, que dirá de organização coletiva autônoma, a internet deveria ser um instrumento de consumo. Já nos anos 1990, livros destinados ao grande público, escritos por alguns dos principais nomes da "revolução" da microinformática, apontavam sem rodeios essa direção (Gates, 1995; Negroponte, 
[1995] 1997; Dertouzos, 1997). E, para recuperar a velha expressão de Maquiavel, eles eram, ao contrário dos utopistas, os "profetas armados", aqueles que dispunham dos meios para implementar suas previsões na realidade (cf. Miguel, 2000).

É fácil perceber hoje que as características da esfera virtual listadas por Papacharissi, citadas acima, são realizadas muito desigualmente. $\mathrm{O}$ acesso à informação é estratificado já a partir da posse diferenciada das ferramentas básicas, tanto cognitivas quanto materiais - grau de alfabetização e domínio da língua franca que concentra boa parte do conteúdo da internet (o inglês), velocidade da conexão disponível. E a reciprocidade da comunicação é limitada pela desigualdade de visibilidade dos diferentes espaços na web, já que um blog obscuro ou um perfil pessoal pouco frequentado não se comparam a um portal de notícias da mídia corporativa ou a uma página turbinada por publicidade. A internet abre a possibilidade de uma eventual subversão dessas hierarquias, nem sempre desejada pelos emissores, o que gera vários dos desdobramentos discutidos neste artigo. Mas isso é a exceção, não a regra. Para a esmagadora maioria das trocas comunicacionais - e, sobretudo, no que se refere à capacidade de influenciar no debate público - permanece uma situação em que a assimetria vigora. Alguns dos gatekeepers tradicionais, em particular o jornalismo, enfrentam problemas para se adaptarem à nova situação e reclamam dos novos competidores. Mas isso não indica o fim da desigualdade, e sim novas maneiras pelas quais ela se efetiva. Indivíduos e grupos carentes de poder econômico largam em severa desvantagem em relação àqueles que podem alavancar suas mensagens por meio de publicidade ou robôs. Um simples exemplo da assimetria do acesso é a prática do zero rating - em que as operadoras de telefonia móvel liberam o uso "gratuito" e "ilimitado" de determinados aplicativos em detrimento de outros. A franquia gratuita do Facebook e do WhatsApp para os mais de 60 milhões de usuários da operadora Claro, apenas no Brasil, cria a ilusão de que a internet se resume a esses aplicativos.

Assim, a experiência dominante dos usuários da internet é a de uma interação que ocorre a partir de espaços privados, mas em um ambiente que é ao mesmo tempo público e dominado pela lógica do capitalismo. Sem entrar na discussão sobre a vigência ou não de uma nova fase, "informacional", da economia capitalista, é possível apontar que os dados pessoais se tornam um bem valioso, na medida em que quem os controla ganha vantagem na concorrência pelo acesso aos consumidores - de mercadorias, de serviços ou de discursos políticos. A extração desses dados torna-se, assim, fundamental para a lucratividade das empresas de tecnologia, ao mesmo tempo que mantém, para seus usuários, a ilusão de que fornece serviços de forma "gratuita".

Um ponto adicional precisa ser incluído no cenário. A internet surgiu como um território aberto, tendendo para o caótico, em que uma miríade de páginas e portais disputavam a atenção dos usuários. Hoje, o grosso do fluxo é controlado pelos 
mecanismos de busca (um mercado quase monopolizado pelo Google) e pelas redes sociais, que medeiam as interaçóes entre as pessoas, enquadram-nas em modelos predeterminados e estabelecem os limites do que é ou não permitido: os "jardins murados" de que fala a literatura sobre o tema.

Essa breve descrição deixa claro que a world wide web não é apenas uma nova ferramenta para viabilizar antigas práticas sociais, mas as reconfigura, já a partir da própria produção das identidades. Nela, mesclam-se informações públicas e privadas - e surge um mercado informacional de dados pessoais, que rapidamente se torna central na reprodução da economia capitalista e coloca em risco o entendimento liberal sobre privacidade. A internet também possibilita novas formas de articulação política e de manifestação de opinião; a fronteira entre expressão privada e declaração pública se desvanece.

Um exemplo, ocorrido na campanha eleitoral brasileira de 2010, é significativo. A questão do aborto tornou-se um tema importante, com о PSDB mirando o eleitorado conservador e acusando o PT de ser favorável à sua legalização. Essa estratégia precisou ser deixada de lado, porém, quando foi revelado que a mulher do candidato José Serra já teria interrompido voluntariamente uma gravidez. A revelação foi feita (por uma ex-aluna dela) em uma página pessoal no Facebook, aparentemente sem intenção de alcançar maior audiência, mas repercutiu graças às "replicações" de outros internautas, acabando por chegar aos meios de comunicação tradicionais. Um comentário privado ganhou alcance público e incidiu nas estratégias políticas de um candidato presidencial.

O caso envolvendo Mônica Serra e sua ex-aluna tomou maior dimensão, mas essa incerteza quanto à visibilidade tornou-se parte do cotidiano. Adolescentes se surpreendem ao descobrir que suas conversas são monitoradas por pais ou professores; funcionários de empresas são punidos por comentários ou fotografias consideradas impróprias. $\mathrm{O}$ alcance da informação é indeterminado e, para todos os efeitos, aleatório. Outro exemplo é esclarecedor: em 2013, uma jovem executiva desconhecida chamada Justine Sacco lançou um "tuíte" considerado racista em sua conta pessoal, com poucos seguidores, antes de embarcar num voo para a África do Sul. Quando chegou a seu destino, horas depois, tornara-se líder dos trendings topics do Twitter e perdera o emprego. No livro em que narra este e outros casos similares, Jon Ronson (2015) está preocupado com o caráter desmedido do julgamento das redes, incapaz de promover uma gradação entre diferentes tipos de faltas, e com os mecanismos psicológicos que levam tantos de nós a se engajarem na produção da humilhação pública de outros. A punição não depende da gravidade do erro, mas da dimensão de sua exposição. Este, portanto, é o ponto de partida: as pessoas não atentam para a possibilidade de uma exposição alargada daquilo que falam ou fazem, exatamente 
porque as interações ocorrem em condições que projetam intimidade (dentro de casa ou por meio de aparelhos eletrônicos pessoais que se tornam verdadeiras extensões do self), esperando atingir um círculo íntimo de amigos e familiares.

No caso de Sacco, coube a ela a iniciativa de "tuitar", sem que esperasse que seu comentário preconceituoso fosse alcançar alguém além de seus escassos contatos pessoais. Em outros casos, a publicização é inesperada e promovida por terceiros. Por um lado, os equipamentos de gravação de áudio e vídeo se tornaram menores, portáteis e - o que é mais importante - sempre disponíveis, já que estão acoplados aos telefones celulares. Com um smartphone na mão, somos todos paparazzi em potencial. Por outro lado, muitas conversas que antes ocorreriam por telefone e sem registro se dão agora por meio de mensagens de texto, ficando armazenadas nos dispositivos dos participantes e podendo ser resgatadas a qualquer momento. Há um permanente registro de interações que continua disponível para outros usos mesmo quando a natureza da relação entre os envolvidos se alterou. É o que ocorre no fenômeno da divulgação de imagens sem consentimento, conhecido como revenge porn, amplamente disseminado e com consequências muitas vezes graves para os envolvidos. As imagens que foram produzidas e compartilhadas num contexto de intimidade e confiança não desaparecem quando estes sentimentos dão lugar a outros, como raiva e ressentimento.

Um episódio que ocorreu com o jornalista William Waack, então na Rede Globo de Televisão, permite um paralelo com a história de Justine Sacco. Waack fez um comentário racista, no estúdio, antes de iniciar uma entrevista. Mais de um ano depois, em dezembro de 2017, o comentário foi postado na internet, por alguém que o gravara sigilosamente; diante da reação pública, a emissora optou por demitir o jornalista. Nos dois casos, declarações que dificilmente teriam qualquer repercussão se tivessem permanecido restritas a um círculo privado geraram comoção e culminaram na demissão dos responsáveis por elas. Mas, além das posições diversas dos envolvidos (Waack já era uma personalidade pública), salta aos olhos uma diferença essencial: enquanto Sacco não se deu conta do alcance potencial de seu “tuíte”, Waack não sabia que seu comentário seria gravado e reproduzido. A permanente possibilidade de gravação e posterior publicização coloca a todos, mas sobretudo políticos e celebridades, em condições de privacidade incerta: nunca se sabe quando algo que deveria permanecer privado pode aparecer diante do público.

É necessário adicionar um novo elemento ao quadro. O potencial de replicação das mensagens pelos indivíduos privados não depende apenas de lançar suas garrafas ao mar, como nos blogs pessoais ou perfis em redes sociais, na incerteza de se e quando alguém vai recolhê-las. É possível direcioná-las para um grupo selecionado de receptores por meio das "listas", que inicialmente foram de correio eletrônico e 
agora são sobretudo de aplicativos de mensagens instantâneas, como WhatsApp, cujos grupos se tornaram muito populares no Brasil. O que se discute nesses meios é privado, pois inclui pessoas que se relacionam no círculo de intimidade (família, vizinhos, colegas de trabalho ou de estudo etc.). Entretanto, pode tornar-se público, uma vez que qualquer participante tem as ferramentas disponíveis para expor as mensagens. O participante pode replicar os conteúdos mesmo sem a autorização do emissor inicial, que assim perde qualquer controle sobre a disseminação da informação. Mais do que qualquer dinâmica na web, são os aplicativos de mensagens instantâneas que evocam a imagem de uma teia de interações comunicativas, virtualmente infinita e incontrolável. A greve dos caminhoneiros no Brasil, em maio de 2018, mostrou o poder das correntes de WhatsApp, que expuseram o caráter meramente protocolar das lideranças oficiais e sustentaram a mobilização de uma categoria espacialmente dispersa (além de dividida por uma multiplicidade de relações laborais diversas entre si).

O caráter "privado" desse tipo de comunicação dificulta o controle da circulação de informações. O Facebook e o Twitter podem impor códigos de conduta e suspender usuários que os violem, dado que as mensagens têm estatuto de comunicação em público, mesmo quando se dirigem a um círculo restrito de contatos pessoais. Já as mensagens de WhatsApp tomam o caráter de trocas interpessoais privadas, ainda quando as mensagens são pensadas para atingir, por meio das replicações, o público mais amplo possível. É impraticável que uma mensagem considerada nociva (notícia falsa, discurso de ódio, exposição não autorizada da intimidade de terceiros) seja extirpada do WhatsApp - até porque elas não têm um ponto fixo de origem, como ocorre nos compartilhamentos de Twitter ou Facebook.

A justificativa padrão, para pessoas atingidas por escândalos como o que alvejou Waack, é que a exposição nas redes descontextualiza e, portanto, distorce palavras e ações. É possível discutir, caso a caso, o quanto essa justificativa é forte. Mas o fato é que o afastamento entre evento e contexto, próprio de toda comunicação tecnologicamente mediada, em que emissor e receptor estão separados no tempo e/ou no espaço, é agravado pelas novas tecnologias. Um caso particularmente relevante é o do Google Street View, serviço lançado em 2007 pelo qual a gigante da tecnologia fornece imagens on-line de ruas de várias cidades do planeta. Mas, ao fixar as imagens, o sistema também fotografou automóveis e pessoas passando na rua ou mesmo dentro de suas casas. Qual a implicação disso? Se uma pessoa está em dado momento em uma determinada rua da cidade, ela está num espaço público, mas sabendo que essa informação - sua presença naquele local - é acessível apenas aos poucos que também estão ali. No momento em que a foto é colocada no Google Street View, qualquer pessoa pode saber quem esteve, naquele momento, naquele lugar e com 
aquelas companhias. É a diferença entre falar na rua, para os passantes, e ter sua fala transmitida pela internet. A transmissão gera uma quebra de privacidade, ainda que o espaço onde ocorre seja público.

Inicialmente o Google se negou a retirar da ferramenta imagens identificáveis (especialmente de pessoas), alegando que elas haviam sido capturadas no espaço público (Nissenbaum, 2009, p. 216). Porém, cerca de um ano após o lançamento do serviço, a empresa cedeu às críticas e desenvolveu um algoritmo que transforma rostos e outras informações consideradas sensíveis em borrões (Shankland, 2008). Foi o reconhecimento de que o entendimento estritamente espacial da distinção entre público e privado, no qual a empresa se escorava antes, não tem como ser sustentado. É o que garante o princípio do sigilo das imagens captadas por câmeras de segurança, mesmo quando elas estão voltadas para vias públicas. Por tudo isso, hoje o debate sobre sistemas de vigilância destaca a necessidade de se discutir a relevância de uma privacidade em público (Nissenbaum, 1997).

Nesse contexto, seria possível compreender esse espaço virtual como um terceiro espaço, uma terceira esfera ou um "electronic elsewhere" (Papacharissi, 2015)? Essa terceira esfera é nem pública nem privada, é a um só tempo pública e privada, ou é intermediária entre o público e o privado? E como ela afeta as democracias contemporâneas? Um impacto que ocorre em múltiplas dimensões: maior possibilidade de expressão e exposição públicas, maior vigilância por parte de poderes tanto estatais quanto privados, ampliação do peso da desigualdade informacional na estratificação social, uma crescente parcela da sociabilidade pública ocorrendo em ambientes geridos por corporações privadas (as redes sociais e seus "códigos de conduta"). São questões que permanecem em aberto.

\section{Existe privacidade on-line?}

Diante de tantos desafios, parte da literatura acadêmica já fala em "fim da privacidade" (Rubenfeld, 2009). Trata-se, afinal, de um valor historicamente datado. Ainda que a ideia de espaços público e privado venha da Roma antiga e que, antes ainda, o pensamento grego trabalhasse com a oposição entre pólis e oikos, a percepção da privacidade que temos hoje é tributária do pensamento liberal e da ascensão da burguesia. É a tradição liberal que faz a liberdade individual repousar na esfera privada, contrapondo-se à perspectiva clássica, que via a liberdade como sendo exercida no ambiente público. A privacidade passa a ser entendida como necessária para a emergência do indivíduo e, portanto, do cidadão. Sem a manutenção de uma esfera individual de autonomia, nenhuma resistência ao despotismo é possível. Com a ampliação dos direitos individuais e o reconhecimento da pluralidade das socieda- 
des contemporâneas, o direito à privacidade "desempenha um papel importante na proteção das capacidades dos indivíduos para formar, manter e apresentar aos outros uma autoconcepção coerente, autêntica e distinta" (Cohen, 1997, p. 142). Formar, manter e apresentar: a privacidade é condição de existência do individualismo ético que está no coração do liberalismo - e, por influência dele, de quase todas as principais correntes políticas e filosóficas contemporâneas, mesmo as que são críticas às insuficiências da abordagem liberal.

Como ocorre com outras características fundantes do homem liberal, a privacidade é sensível às posições de classe, de gênero e de raça. Quando o "direito à privacidade" começa a ser codificado, no século XIX, os burgueses reivindicavam ser deixados em paz pela nascente imprensa de fofocas, enquanto a população pobre dificilmente teria acesso a tal luxo - não por algum interesse do jornalismo marrom, mas pelo simples fato de ter que dividir a moradia, em espaços que não permitiam qualquer isolamento e intimidade. As mulheres, por sua vez, sofriam o controle público de seus corpos, mesmo aquelas das classes sociais privilegiadas.

Não se trata apenas das condições materiais. A garantia oferecida pelo Estado para a privacidade é diversa, conforme o grupo atingido, como mostram cotidianamente operações policiais em regiôes pobres - invasões de casas e revistas pessoais são rotina, ao contrário do que ocorre com os mais ricos. Juízes, no Brasil, expedem mandados de busca e apreensão coletivos para favelas, o que significa a suspensão localizada do preceito constitucional da inviolabilidade do domicílio ${ }^{1}$. No ambiente de trabalho, são frequentes denúncias de revistas íntimas, às quais são submetidas sobretudo funcionárias do sexo feminino ${ }^{2}$.

Ao mesmo tempo, é importante não negligenciar o caráter relacional e contextual do que é privado (Cohen, 1997; Nissenbaum, 2009). Nesse sentido, a privacidade se refere à intimidade e às trocas entre o eu e o outro. Não se trata de algo que se defina primariamente pela metáfora espacial das esferas, mas que remete à manutenção da autonomia pessoal na relação com o mundo exterior.

Assim, a possibilidade de deciframento do self por meio do processamento computadorizado de informações, com a consequente abertura para estratégias de indução de comportamentos, representa uma quebra da privacidade. Como diz Nissenbaum sobre os desafios à privacidade em contextos em que a mediação computacional se torna onipresente, "impulsionados por um alto poder de processamento, técnicas matemáticas e estatísticas cada vez mais sofisticadas tornaram possível extrair signifi-

1. A legalidade de tais autorizações é contestada; no entanto, elas continuam sendo emitidas.

2. Fábricas de lingerie, em especial, adotam a prática, sob a justificativa de impedir o furto de peças. Vedada por lei e considerada abusiva por diversas decisões da Justiça do Trabalho, ela ainda assim continua ocorrendo (Roesler, 2018). 
cados descritivos e preditivos de informações" (Nissenbaum, 2009, p. 42). A autora se refere a fenômenos como a big data, o machine learning e a inteligência artificial dos algoritmos, todos baseados na exposição "espontânea" que somos levados a estabelecer nas redes.

São informações coletadas durante a navegação na web ou então pelo simples fato de se portar um dispositivo móvel - que envia incessantemente informações sobre os usuários, a ponto de que, como escreveu Mc Chesney (2013, p. 150), não deveriam ser chamados de smartphones e sim de "rastreadores". Juntam-se a isso os cadastros de lojas e operadoras de crédito, que formam o registro detalhado do cidadão como consumidor. A conta da farmácia revela de que enfermidade padeço, a do pet shop qual é meu bichinho de estimação, a da loja de brinquedos quantos anos têm meus filhos - e assim por diante. Na medida em que, sob a alegação de "praticidade", o cadastro, sobretudo no comércio informatizado e on-line, é feito muitas vezes por meio das contas em redes sociais, a interconexão das bases de dados torna-se quase total. Cada bit de informação é insignificante em si mesmo. Mas, quando combinados, tratados e cruzados, os dados produzem um enorme conhecimento sobre hábitos, comportamentos, valores e padrões de interação social de cada indivíduo. O resultado é que, cada vez mais vulneráveis à ação de máquinas que parecem saber mais de nós do que nós mesmos, estamos perdendo nosso próprio espaço interior como espaço de privacidade.

Os algoritmos foram escritos inicialmente para impulsionar anúncios. A "propaganda personalizada", que exibe a cada potencial consumidor aquilo que se imagina que mais possa sensibilizá-lo, amplia o poder predatório da publicidade comercial, que busca colonizar não apenas o espaço público, mas todo o universo mental de seus receptores, orientando suas aspirações e seu sentido de realização pessoal para o consumo de determinados produtos. A segmentação do público, que permite a publicidade direcionada, não é novidade para o mercado, mas agora alcança precisão milimétrica. Quando mais ajustada é a propaganda, atingindo as predisposições pessoais mais profundas, menor é a capacidade de defesa contra ela.

Hoje, além dessa função inicial, os algoritmos cumprem muitos outros fins, notadamente o direcionamento das inclinações políticas. Quanto mais nossas escolhas são dirigidas a partir de uma publicidade individualizada, gerada por meio de uma massa de dados coletados previamente, menor é o espaço para o exercício da autonomia (Meireles, 2016). Todo o modelo da democracia liberal, que coloca na base das decisões políticas a escolha autônoma de cada decisão, fica em xeque.

Nissenbaum destaca que há uma "mudança na natureza da coleta de dados, realizada de forma automatizada e indiscriminada" (2009, p. 21). Não se trata mais de uma exposição aos dispositivos eletrônicos, mas de máquinas “aprendendo o 
que podem sobre as pessoas, seus atributos e ações passadas, em um esforço para entender suas predisposições e prever ações futuras" (Nissenbaum, 2009, p. 42). A atuação dessas empresas tem como gesto inaugural, então, a reivindicação unilateral de toda "experiência humana como matéria-prima grátis para tradução em dados comportamentais" (Zuboff, 2019, p. 8).

O conhecimento daí advindo é usado para estimular o consumo, para orientar a direção da ação social e também para reter a atenção das pessoas, fazendo com que uma parcela cada vez maior do tempo seja despendida dentro dos "jardins murados" da internet. Isso implica a submissão a uma dinâmica de relações que é própria da vida dentro desses condomínios virtuais, como a busca incessante pela aprovação expressa de quem nos cerca (a "cultura do like”), e também a regras de convivência determinadas pelas empresas, que não são necessariamente aquelas dos Estados ou de uma ética comum - a censura do Facebook a fotos de mulheres amamentando é um simples exemplo disso. Em suma, os algoritmos estão transformando o conjunto das relações sociais, dentro e fora da rede de computadores.

Nesse contexto, a expansão das tecnologias digitais fez com que a privacidade perdesse valor para as pessoas e ganhasse para o mercado, em um fenômeno definido como "capitalismo de vigilância" (Zuboff, 2019). Os dados pessoais são obtidos por um crescente número de corporações e governos. A vigilância dos serviços estatais de inteligência sobre as comunicações digitais é onicompreensiva. A ampla capacidade de armazenamento hoje existente permite que grande parcela do tráfego de informações on-line seja gravada mesmo sem haver interesse específico em relação a elas; as ameaças da criminalidade, alimentadas por uma mitologia incessante sobre os horrores da deep web - os "quatro cavaleiros do infoapocalipse", isto é, lavagem de dinheiro, drogas, terrorismo e pornografia infantil (Assange, [2012] 2013) justificam toda e qualquer intrusão.

A defesa liberal de uma esfera privada imune à supervisão pública ligava-se também à ideia de que cabia ao Estado apresentar os indícios de transgressão da lei antes de investigar qualquer cidadão. A internet não é o único fator, mas concorre no processo de reversão desse entendimento, em que as garantias antes vigentes são suspensas e o princípio da presunção de inocência reflui; a característica de ser um ambiente que mantém registro de todas as interações torna-a particularmente favorável ao exercício da vigilância estatal distendida. E os procedimentos de criptografia que poderiam dar alguma proteção aos cidadãos tendem a ser pouco acessíveis e trabalhosos, o que limita seu uso.

No caso das corporações, embora não seja infrequente o uso não autorizado de informações, vigora em geral a cessão "voluntária” de dados pessoais, que se dá por meio do contrato de acesso ao serviço, ferramenta ou aplicativo. Conhecidos como 
termos de uso, esses contratos se assemelham a bulas de remédios; extensos, com letras pequenas e por vezes incompreensíveis. Ou seja, são feitos para não serem lidos. As políticas de privacidade de sites e aplicativos defendem que os dados são coletados para melhorar a "experiência de uso" das pessoas, que seriam beneficiadas com indicações personalizadas. No entanto, as pessoas raras vezes são capazes de compreender as implicações das autorizações que estão concedendo. Permitir que uma máquina registre sua localização ou rastreie suas mensagens parece um preço pequeno a pagar, se o que se obtém em troca são informações atualizadas sobre trânsito e clima, um programa gratuito de correio eletrônico ou a possibilidade de ditar textos.

Mesmo que as pessoas compreendam, eles têm poucas alternativas. Não há margem de negociação. Ou se adere ao contrato padrão determinado pelas empresas ou não há acesso ao serviço. É possível cancelar alguns serviços do computador ou do smartphone, mas o custo de recusar todas as tecnologias invasivas tende a ser alto, tanto em termos profissionais quanto pessoais. No mundo urbano contemporâneo, exceto para os muitíssimo pobres e para as crianças muito pequenas, a expectativa é que todos estejam conectados. Para a maior parte das pessoas, a recusa a ter um cartão de crédito, a usar serviços de telefonia móvel, a acessar a internet ou mesmo a participar de mídias sociais possui consequências que não são banais, com a exclusão de grupos de pertencimento, perda de oportunidades de trabalho e alienação em relação ao "chão comum" de atividades e de interesses que é fundamental para o exercício da sociabilidade. No limite, o risco é o insulamento na condição de "pária” social.

Parte - mas não a totalidade - dos problemas poderia ser contornada com a busca de alternativas fora das grandes empresas da informática. Mas isso exige uma pessoa explicitamente preocupada com o problema, em condições de romper a inércia que o ambiente dominado pelas megacorporações impõe. Sistemas operacionais como o Windows são conhecidos por suas falhas de segurança e também pela permanente supervisão e registro da atividade dos usuários. No entanto, o sistema da Microsoft é o dominante, graça às facilidades de uso - pré-instalação nas máquinas dos maiores fabricantes, uniformidade de interface dos softwares mais populares, compatibilidade imediata com a maior parte dos serviços fornecidos pela internet, inclusive serviços do poder público, sensíveis ao lobby das grandes corporações da informática. O uso dos derivados do Linux fica restrito a "nerds" ou "paranoicos".

Essa coleta de dados pessoais, realizada de forma sem precedentes, impõe riscos à intimidade e à privacidade, pois a tela que conecta as pessoas a essas tecnologias se encontra na esfera privada. Pode-se dizer que "o paradoxo da experiência on-line é que ela possibilita às pessoas se comunicarem umas com outras na privacidade de suas casas, ao mesmo tempo que as expõe ao monitoramento e rastreamento" (Nis- 
senbaum, 2009, p. 27). Em outras palavras, o acesso à tela - seja do computador ou smartphone - ocorre na maioria das vezes de forma individualizada e privada, mas ao mesmo tempo é tudo registrado, até mesmo a movimentação do cursor.

Fica evidente que um grande desafio à privacidade na era digital se refere ao controle sobre as próprias informações - a "privacidade informacional”, que permite que eu decida quais fatos da minha vida particular serão expostos ao público e quais não. Trata-se de proteger uma esfera de intimidade que é mais restrita até do que a percepção corrente do privado como doméstico e que se confunde com o próprio eu (Cohen, 1997).

A autoridade política tem dificuldade de garantir a vigência dos direitos de privacidade, por um conjunto entrelaçado de motivos, entre os quais destacamos três: (1) A evolução tecnológica é muito acelerada, em descompasso com o ritmo lento da formulação, negociação e adoção de normas legais. (2) O mercado dos dados on-line é dominado por corporações gigantescas com enorme capacidade de resistência e de pressão, sobretudo diante de Estados aparentemente debilitados pela chamada "globalização". (3) Não há nenhum interesse econômico que se mobilize em defesa da privacidade de dados.

Até o momento, o maior passo para reduzir a capacidade de absorção de dados pelas empresas de tecnologia é a Regulação Geral de Dados Pessoais (RGDP) da União Europeia, que passou a vigorar em maio de 2018. Trata-se de um regulamento que tem como objetivo a proteção da privacidade e dos dados pessoais dos cidadãos do bloco. Cada pessoa deve ter o direito de escolher o que vai ser coletado e por quem, colocando ênfase na necessidade de consentimento esclarecido, entre outros direitos. A vigência da RGDP é recente e seu impacto não está totalmente claro, mas as empresas reagiram - a começar pela redistribuição dos usuários em suas filiais, para que o menor número possível deles ficasse sob a jurisdição da nova lei (Untersinger, 2018). Ao mesmo tempo, o escândalo sobre a influência russa nas eleições americanas de 2016 colocou em pauta a necessidade de regular a coleta de dados também nos Estados Unidos, em geral avesso a controles estatais mais rígidos.

\section{Conclusão: um espaço intermediário?}

Diante deste quadro, será possível concluir que a internet forma um espaço intermediário entre o público e o privado? A resposta mais plausível parece ser outra. Ao embaralhar a distinção entre as duas esferas, a internet nos ajuda a lembrar que elas não são uma descrição imediata da realidade, mas conceitos, isto é, construtos com finalidade heurística e cujo sentido é também contextual. O que a internet produz é um novo conjunto de práticas sociais, que não se enquadra facilmente no modelo 
mental sedimentado que organiza nossa compreensão do público e do privado.

Ao mesmo tempo, a reflexão sobre as transformações em curso revela com clareza o duplo movimento, aparentemente (mas só aparentemente) paradoxal, em que a privatização das relações humanas se combina com o fim da privacidade. As novas tecnologias permitem a emergência de formas de economia colaborativa, o que leva alguns a vaticinarem, uma vez mais, sua incompatibilidade com a permanência do capitalismo (Mason, [2015] 2017). Mas esse potencial é contrabalançado pelo primado do mercado como mediador das próprias relações em rede, dada a arquitetura dos ambientes virtuais, e pelo estímulo ideológico reforçado ao individualismo e ao consumismo. O fato é que, na internet, nossas ações públicas (por estarem expostas) são inseridas em engrenagens privadas de corporações em busca de lucro e que usam o trabalho não remunerado de seus usuários - o que ocorre cada vez que curtimos algo ou postamos no Instagram, no Facebook ou no Blogger - para fisgar fatias crescentes do tempo, da atenção e da energia... das próprias pessoas.

O reverso necessário da moeda é a permanente captura e tratamento das informações pessoais, que é tanto um dos negócios centrais das grandes corporações da internet quanto um dos instrumentos que permitem a modulação do espaço virtual para que as pessoas não escapem dele. Nossa experiência em rede torna-se, em grande medida, a experiência de viver num mundo privatizado sem privacidade.

A reivindicação pelo direito à privacidade on-line, com o controle sobre os próprios dados pessoais, é a busca da restauração de uma velha bandeira liberal, adaptada à situação em que vivemos, de sociabilidade tecnologicamente mediada. Ao mesmo tempo, cresce a preocupação com aquilo que alguns filósofos políticos estão chamando de "o comum" (Hardt \& Negri, [2009] 2016), que se liga ao desconforto com a expansão do caráter mercantil das relações humanas, na atual fase do capitalismo, è̀ necessidade de reconstrução do espaço público - e de um espaço público orientado por valores societários diversos ou, mais ainda, opostos aos que regem a lógica da competição capitalista. "Público" e "privado", portanto, não parecem ferramentas analíticas obsoletas para informar um olhar crítico sobre o mundo social. Mas precisam, cada vez mais, ser entendidas de forma contextual e desvinculadas da metáfora espacial que as fixa como esferas predeterminadas. 
Referências bibliográficas

Assange, Julian. ([2012] 2013), Cypherpunks: liberdade e o futuro da internet. São Paulo, Boitempo.

Benkler, Yochai. (2006), The wealth of networks. New Haven, Yale University Press.

BRUNo, Fernanda (2008), "Monitoramento, classificação e controle nos dispositivos de vigilância digital”. In: Antoun, Henrique (org.). Web 2.0. Rio de Janeiro, Mauad x.

Cohen, Jean L. (1997), “Rethinking privacy”. In: Weintraub, Jeff \& Kumar, Krishan (eds.). Public and private in thought and practice. Chicago, The University of Chicago Press.

Dantas, Marcos (2010), “Convergência digital: entre os 'jardins murados' e as praças públicas”. In: SEL, Susana (comp.). Politicas de comunicación del capitalismo contemporâneo. Buenos Aires, Clacso.

Dertouzos, Michael. (1997), O que será: como o novo mundo da informação transformará nossas vidas. São Paulo, Companhia das Letras.

Frezza, Bill. (5 jun. 1995), "Internet: killer virus of the State”. Interactive Age: 13.

Gates, Bill. (1995), A estrada do futuro. São Paulo, Companhia das Letras.

Hardt, Michael \& Negri, Antonio. ([2009] 2016), Bem-estar comum. Rio de Janeiro, Record.

KANT, Immanuel. ([1796] 1995), “A paz perpétua”. In: A pazperpétua e outros opúsculos. Lisboa, Edições 70 .

LÉvy, Pierre. (1994), L’intelligence collective. Paris, La Découverte.

Lyon, David. (2017), “Surveillance culture”. International Journal of Communication, 11: 824-42.

Mason, Paul. ([2015] 2017), Pós-capitalismo. São Paulo, Companhia das Letras.

Mc Chesney, Robert. (2013), Digital disconnect. Nova York, The New Press.

Meireles, Adriana Veloso. (2016), “Autonomia e privacidade no ambiente digital”. Revista Eletrônica de Ciência Politica, 7 (2): 4-22.

Miguel, Luis Felipe. (2000), “As novas tecnologias e a democratização da informação”. Lugar Comum, 9-10: 133-45.

Negroponte, Nicholas. ([1995] 1997), A vida digital. São Paulo, Companhia das Letras.

Nissenbaum, Helen. (1997), “Toward an approach to privacy in public". Ethics and Behavior, 7 (3): 207-19.

Nissenbaum, Helen. (2009), Privacy in context. Stanford, Stanford University Press.

PapaCharissi, Zizi. (2009), “The virtual sphere 2.0”. In: CHAdwick, Andrew \& Howard, Philip N. (eds.). Routledge handbook of Internet politics. Abingdon, Routledge.

Papacharissi, Zizi. (2015), Affective publics. Oxford, Oxford University Press.

Roesler, Átila. (22 jul. 2018), “Sobre a nova Lei n. 13.271/2016 e a revista íntima e de pertences de trabalhadores”. Juizes para a Democracia. Disponível em http://ajd.org.br/ sobre-a-nova-lei-n-13-271-2016-e-a-revista-intima-e-de-pertences-de-trabalhadores/, consultado em 13/08/2018. 
Ronson, Jon. (2015), Humilhado: como a era da internet mudou o julgamento público. Rio de Janeiro, BestSeller.

Rubenfeld, Jed (2009), “Privacy’s end”. In: Powell, H. Jefferson \& White, James Boyd (eds.). Law and democracy in the empire of force. Ann Arbor, The University of Michigan Press.

Shankland, Stephen. (13 maio 2008), "Google begins blurring faces in Street View”. C-Net. Disponível em https://www.cnet.com/news/google-begins-blurring-faces-in-street-view/, consultado em 11/01/2018.

Untersinger, Martin. (19 abr. 2018), "Facebook prive 1,5 milliard d'utilisateurs du droit européen sur les donnés”. Le Monde: 5.

Weintraub, Jeff. (1997), “The theory and politics of the public/private distinction”. In: Weintraub, Jeff \& Kumar, Krishan (eds.). Public and private in thought and practice. Chicago, The University of Chicago Press.

Zuboff, Shoshana. (2019), The age of surveillance capitalism. Nova York, Public Affairs.

\section{Resumo}

O fim da velha divisão? Público e privado na era da internet

A emergência da internet impôs desafios à distinção público/privado - que é estruturadora de muitos modelos que pensam o mundo social, de instituições e de normas jurídicas. (1) A homologia entre localização espacial e acesso a uma ou outra esfera é cada vez menos sustentável. (2) Há uma transição sem solução de continuidade da comunicação privada para a exposição pública. (3) A exposição pública perde seu contexto, já que pode ser reprodutível para qualquer outra audiência. (4) A privacidade fica em suspenso diante da vigilância sobre as trocas comunicativas on-line, incluindo aquelas que seriam privativas. $\mathrm{O}$ artigo analisa os efeitos da disparidade entre os pressupostos da normatização jurídica vigente e a experiência socialmente estruturada. Palavras-chave: Internet; Distinção público-privado; Privacidade; Democracia; Vigilância.

\section{Abstract}

The end of the old division? Public and private in the internet age

The emergence of the internet posed substantial challenges to the public/private distinction, that is structuring in many models that think about the social world, the institutions and legal norms. (1) The homology between spatial location and access to one or another sphere is increasingly less sustainable. (2) There is a transition without solution from private communication to public exposure. (3) The public exposure loses its context, since it can be reproduced to any other audience. (4) Privacy remains on hold before the vigilance on the online communicative exchanges, including the ones that would be private. The text analyses the effects of the disparity between the assumptions of the current legal norm and the socially structured experience.

Keywords: Internet; Public-private distinction; Privacy; Democracy; Vigilance. 
Texto recebido em 15/10/2020 e aprovado em 05/03/2021.

DOI: $10.11606 / 0103-2070 . t s .2021 .176201$.

Luis Felipe Miguel é professor titular do Instituto de Ciência Política da Universidade de Brasília, onde coordena o Grupo de Pesquisa sobre Democracia e Desigualdades (Demodê), e pesquisador do CNPq. E-mail: luisfelipemiguel@gmail.com.

Adriana Veloso Meireles é doutora em ciência política pela Universidade de Brasília. E-mail: dricaveloso@gmail.com.

(c) $(1)(9$ 